\title{
Fast Ion Chromatographic Method for the Determination of Formates in Alcoholic Drinks
}

\author{
Maria Balcerzak $^{1}$ - Dawid Kapica ${ }^{1}$ \\ Received: 27 September 2016 / Accepted: 10 January 2017 / Published online: 16 January 2017 \\ (C) The Author(s) 2017. This article is published with open access at Springerlink.com
}

\begin{abstract}
Monitoring of human exposure to formic acid is important due to its high biological activity. Elevated amounts of formic acid in the human body can cause serious damage to optical nerve, respiratory failure, renal failure, deep metabolic acidosis, coma, and eventual death from cardiovascular arrest. Such symptoms are characteristic for methanol poisoning owing to rapid enzymatic conversion of methanol into formic acid of substantially higher than methanol alone toxicity. Early diagnosis of methanol consumed and formic acid produced is essential for successful medical treatment. Small amounts of methanol can be introduced into the human body with alcoholic drinks (methanol can be a by-product of distillation and fermentation processes). A fast method for the determination of formates in commercial alcoholic drinks by the use of suppressed ion chromatography (IC) with conductometric detection has been developed. The applicability of two anion-exchange columns, Metrohm Metrosep A Supp 7 and Dionex IonPac AS9-HC, for selective detection of formates in mixtures with acetates and common inorganic ions occurring in such kind of samples was examined. Quantitative isolation of formates from the matrix can be reached in less than $10 \mathrm{~min}$ using $3.6 \mathrm{mmol} / \mathrm{L} \mathrm{Na}_{2} \mathrm{CO}_{3}$ as an eluent. Preliminary minimizing of alcoholic matrix by the evaporation (under IR source) allows to improve the quality of chromatographic results. The evaluated amounts of formates in two different Polish commercial products, "Absolwent vodka" and "Golden Rum," tested in the work were in the
\end{abstract}

Maria Balcerzak

mbal@ch.pw.edu.pl

1 Department of Analytical Chemistry, Warsaw University of Technology, Noakowskiego 3, 00-664 Warsaw, Poland range of $0.2-3.1 \mathrm{mg} / \mathrm{L}$. The $96-107 \%$ recoveries of the formates from the examined samples were found out.

Keywords Ion chromatography $\cdot$ Formates $\cdot$ Alcoholic drinks $\cdot$ Anionic profile

\section{Introduction}

High biological activity of formic acid generates the interest in monitoring of its sources for humans. The elevated level of the acid occurring in the human body can cause significant fatal effects such as serious damage to optical nerve, respiratory failure, hepatic and renal failure, and coma. Blood concentrations above $10 \mathrm{mmol} / \mathrm{L}(0.5 \mathrm{mg} / \mathrm{mL})$ can induce deep metabolic acidosis and lead to death (Kinoshita et al. 1998; Tanaka et al. 1991). Formic acid can enter the human body through diet, production by intestinal microflora, and, as a result, methanol ingestion or inhalation of its vapors. Methanol ingestion is the most important source of high concentrations of formates in body fluids and tissues. Methanol is rapidly, within 2-24 $\mathrm{h}$ after ingestion, metabolized (dehydrogenated) by alcohol dehydrogenase $(\mathrm{ADH})$ to formaldehyde and further to formic acid of substantially higher than methanol toxicity (Hovda et al. 2005; Kinoshita et al. 1998; Kruse 1992; Wallage and Watterson 2008). The content of formate in blood is a marker of methanol intoxication. Its rapid screening in the human body is of great significance for clinical diagnosis. High concentration of formic acid, corresponding to those related to fatal methanol poisonings, can be found in putrefied postmortem physiological fluids, presumably due to bacterial action and decomposition of lipids, carbohydrates, and proteins (Viinamäki et al. 2011).

Small amounts of methanol can occur in commercial alcoholic drinks as a by-product of fermentation and distillation 
steps (5.2-85.6 mg/L in vodkas (Arbuzov and Savchuk 2002) and $3.1-4.6 \mathrm{mg} / 100 \mathrm{~mL}$ ethanol in rums (Lachenmeier et al. 2003)). Wide consumption of alcoholic beverages can make a source of formic acid for humans (Kapur et al. 2007). Until now, data on the content of formates in such products are scarce. Analytical control of the sources of formic acid for humans is of great value for the general food industry. Organic acids, including formic acid, can affect sensory properties of food items as well as their stability.

Gas chromatography (Lee et al. 2012; Lee et al. 2013; Ligor et al. 2008; Ryhl-Svendsen and Glastrup 2002; Sokoro et al. 2007), capillary electrophoresis (Klampfl et al. 2000; Kubáñ and Boček 2013; Kubáň et al. 2013; Kubáň et al. 2014; Pantučkova et al. 2013; Suárez-Luque et al. 2006; Travassos Lemos et al. 2015), and ion chromatography (Brudin et al. 2010; Käkölä et al. 2008; Kuo 1998; Lodi and Rossin 1995; Magne et al. 1998; Rantakokko et al. 2004; Walford 2002; Wojtczak et al. 2013) are techniques most often used for the determination of low-molecular-mass carboxylic acids in various materials, including food products. Complications arising from the major sample components, e.g., proteins, lipids, and salts, in the examination of the samples of biological matrices, can generate the necessity of coupling of the technique with a suitable sample preparation step for their elimination.

Ion chromatography (IC) is a technique widely applied in the investigations of ionic components of various materials (Weiss 2004). Fast, simple, and selective determination of inorganic and small organic ionic species in one run makes the technique competitive to the other instrumental techniques. Little sample preparation steps and small samples required for analysis are the advantages of IC analytical procedures. The possibility of the use of ion chromatography for rapid identification and quantification of small organic acids, among them formic acid, in various food and beverages samples was documented (Lodi and Rossin 1995; Magne et al. 1998; Walford 2002; Brudin et al. 2010; Wojtczak et al. 2013). The content of organic acids in foods can serve as a marker of degradation and fermentation processes occurring during production and storage steps. The IC technique is particularly suitable for direct examination of the occurrence of small organic acids in drinking waters, among them those being byproducts of ozonation processes (Kuo 1998; Rantakokko et al. 2004). Such compounds can be consumed by microorganisms stimulating their regrowth. Simultaneous inorganic (cations and anions) multicomponent analytical results can make the basis of the differentiation in the originality of alcoholic products (Arbuzov and Savchuk 2002; Lachenmeier et al. 2003). Reliable determination of formates and acetates in the presence of inorganic anions requires careful optimization of the IC analytical procedure for effective baseline separation of formate, acetate, and fluoride signals exhibiting close retention times (Kontozova-Deutsch et al. 2008; KontozovaDeutsch et al. 2011; Janiszewska and Balcerzak 2013).
In the present work, a rapid method for the determination of formates in vodka and rum products, differing in production processes, by the use of suppressed anionic IC with conductometric detection was developed. Vodka is produced by rectifying ethyl alcohol, the product of fermentation of grains (wheat, rye, corn), potatoes, sugar beets, and fruits. The distillation products (of 96-97\% alcohol content) are diluted with water usually to alcohol level below $40 \%$ prior to bottling. Rum is a distilled alcoholic beverage made from sugarcane by-products (molasses or syrup) or sugarcane juice. The distilled spirits are diluted with water to $60-70 \%$ of alcohol and aged (usually for a year) in oak barrels. During aging, the rum acquires golden color.

\section{Materials and Methods}

\section{Apparatus}

The 761 Compact IC System from Metrohm AG (Herisau, Switzerland) with a MSM II (Metrohm Suppressor Module) suppressor and a conductometric detector was used. Anion separations were investigated with the use of two different chromatographic columns, Metrosep A Supp $7(250 \mathrm{~mm} \times 4 \mathrm{~mm})$ from Metrohm, Switzerland, and IonPac AS9-HC $(250 \mathrm{~mm} \times 4 \mathrm{~mm})$ from Dionex, USA (the volume of a sample injection loop was $20 \mu \mathrm{L}$ ). Data acquisition and evaluation of chromatograms were carried out with the IC Net 2.3 Metrodata (Metrohm) software.

An infrared (IR) radiation lamp was used for sample evaporation.

Filters of $0.45 \mu \mathrm{m}$ pore size (MCE, Fisherbrand) were used for sample filtration throughout experiments.

\section{Reagents}

All reagents used were of analytical grade. Water purified in a Millipore Elix3/Simplicity UV system (a specific resistance $>18.2 \mathrm{M} \Omega \mathrm{cm}$ ) was used in all experiments.

Standard solutions of formate and acetate were prepared from high-purity acids (from Fluka) dedicated to IC and containing $1000 \pm 4 \mathrm{mg} / \mathrm{L}$ of each anion. Standard solutions of inorganic anions (fluoride, chloride, bromide, nitrate(V), phosphate, and sulfate) were prepared from high-purity sodium salts (from Fluka) containing $1000 \pm 4 \mathrm{mg} / \mathrm{L}$ of each anion and dedicated to IC.

The eluent of $3.6 \mathrm{mmol} / \mathrm{L}$ of sodium carbonate prepared by dissolution of $381.6 \mathrm{mg}$ of $\mathrm{Na}_{2} \mathrm{CO}_{3}$ (from Fluka) in $1 \mathrm{~L}$ of deionized water was used.

\section{Alcoholic Drinks Examined}

Two different Polish industrial alcoholic products, pure vodka (Absolwent) and rum (Golden Rum), were bought on the local 
market. The samples taken from commercial bottles were directly analyzed by the analytical procedure described below.

\section{Analytical Procedure}

Alcohol samples of 5-50 mL were transformed into a $50-\mathrm{mL}$ beaker and evaporated to ca. $1 \mathrm{~mL}$ under IR lamp $(20 \mathrm{~cm}$ distance between the lamp and the sample surface). Each evaporated sample was diluted to $5.0 \mathrm{~mL}$ with deionized water and submitted to chromatographic analysis after filtration through a $0.45-\mu \mathrm{m}$ filter.

\section{Results and Discussion}

Formate is a small organic anion of ion chromatographic signal registered under the conditions commonly used for the determination of inorganic anions. The ion chromatogram of the mixture of formate and some inorganic anions $\left(\mathrm{F}^{-}, \mathrm{Cl}^{-}\right.$, $\mathrm{NO}_{2}{ }^{-}, \mathrm{Br}^{-}, \mathrm{NO}_{3}{ }^{-}, \mathrm{HPO}_{4}{ }^{2-}$, and $\mathrm{SO}_{4}{ }^{2-}$ ) registered when using a very popular anion-exchange A Supp 5 Metrohm column, $\mathrm{Na}_{2} \mathrm{CO}_{3}+\mathrm{NaHCO}_{3}$ eluent, and conductometric detection is given in Fig. 1. Acetate and oxalate are organic acids which signals can also be registered under such conditions. Close retention times of formate, acetate, and fluoride ions can provide problems with quantification of particular anions in the samples containing all of them.

A kind of chromatographic column and an eluent applied limit the effectiveness of the separation of formate ion signal from those of acetate and inorganic anions in case of their occurrence in the examined sample. In this work, the effectiveness of two anion-exchange columns, Metrosep A Supp 7 from Metrohm and IonPac AS9-HC from Dionex, in the separation of $\mathrm{F}^{-}, \mathrm{CH}_{3} \mathrm{COO}^{-}$, and $\mathrm{HCOO}^{-}$ions and quantification of formates was examined. Both columns are dedicated to the

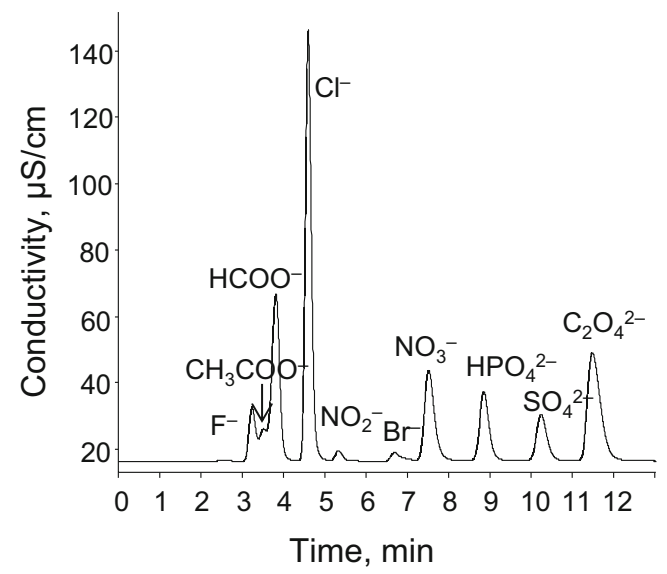

Fig. 1 The ion chromatogram of synthetic mixture of formate, acetate, and common inorganic anions registered with Metrohm Metrosep A Supp 5 chromatographic column $\left(3.2 \mathrm{mmol} / \mathrm{L} \mathrm{Na}_{2} \mathrm{CO}_{3}+1.0 \mathrm{mmol} / \mathrm{L}\right.$ $\mathrm{NaHCO}_{3}$ eluent)

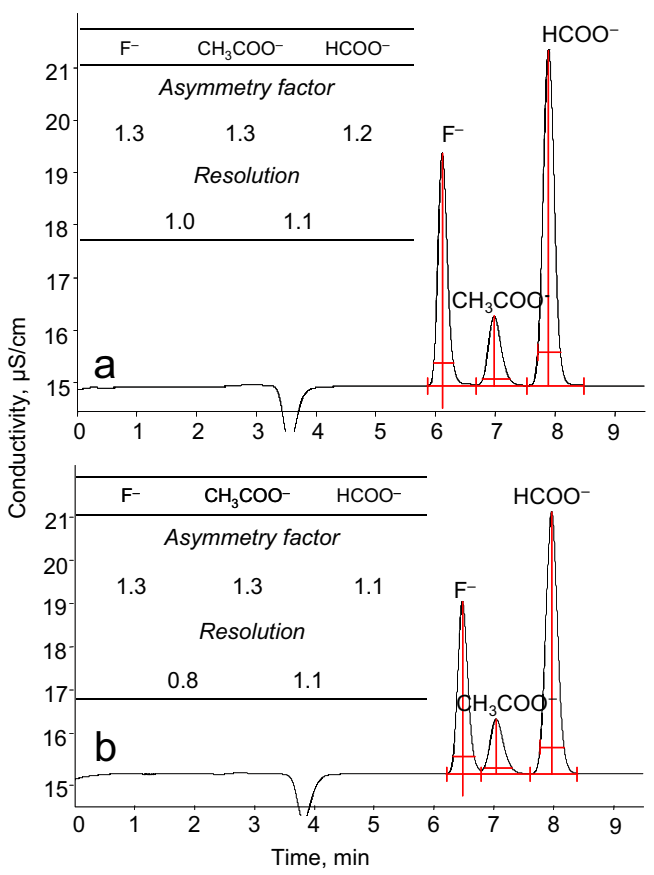

Fig. 2 The chromatograms of synthetic mixture of formate $(10 \mathrm{mg} / \mathrm{L})$, acetate $(10 \mathrm{mg} / \mathrm{L})$, and fluoride $(2 \mathrm{mg} / \mathrm{L})$ ions, and the values of asymmetry factors and resolutions obtained with the use of a Metrohm Metrosep A Supp 7 and b Dionex IonPac AS9-HC (3.6 mmol/L Na $\mathrm{CO}_{3}$ eluent, $0.7 \mathrm{~mL} / \mathrm{min}$ )

determination of inorganic and small organic anions occurring in the examined solutions. The experiments carried out have shown that complete resolution of fluoride, acetate, and formate signals is possible with both columns and $\mathrm{Na}_{2} \mathrm{CO}_{3}$ as an eluent. Figure 2 presents the ion chromatograms of the mixture of the ions obtained with the use of the examined columns and the same $\left(3.6 \mathrm{mmol} / \mathrm{L} \mathrm{Na}_{2} \mathrm{CO}_{3}\right.$ ) eluent. Both columns exhibited similar effectiveness in the separation of $\mathrm{F}^{-}$, $\mathrm{CH}_{3} \mathrm{COO}^{-}$, and $\mathrm{HCOO}^{-}$ions. The Metrosep A Supp 7 column was chosen for further studies owing to shorter analysis time of the samples containing the other inorganic anions $\left(\mathrm{Cl}^{-}\right.$, $\mathrm{NO}_{2}^{-}, \mathrm{Br}^{-}, \mathrm{NO}_{3}{ }^{-}, \mathrm{HPO}_{4}{ }^{2-}, \mathrm{SO}_{4}{ }^{2-}$ ) usually occurring in food products and giving IC signals under the conditions used. The separation of all ions was possible in shorter, ca. $35 \mathrm{~min}$, time on the Metrosep A Supp 7 column as compared with ca.

Table 1 Statistical data for formate IC results $(n=3)$ in mixtures with acetates and fluorides

\begin{tabular}{ccccc}
\hline \multicolumn{2}{l}{ Concentration, $\mathrm{mg} / \mathrm{L}$} & \multicolumn{2}{c}{$\mathrm{HCOO}^{-}$determined $\pm \mathrm{SD}, \mathrm{mg} / \mathrm{L}$} & $\mathrm{RSD}, \%$ \\
\cline { 1 - 3 } $\mathrm{HCOO}^{-}$ & $\mathrm{CH}_{3} \mathrm{COO}^{-}$ & $\mathrm{F}^{-}$ & & \\
\hline 0.5 & 0.5 & 0.1 & $0.50 \pm 0.02$ & 0.4 \\
1.0 & 1.0 & 0.2 & $0.98 \pm 0.01$ & 0.9 \\
2.0 & 2.0 & 0.4 & $1.98 \pm 0.01$ & 0.4 \\
5.0 & 5.0 & 1.0 & $5.02 \pm 0.02$ & 0.3 \\
10.0 & 10.0 & 2.0 & $10.01 \pm 0.03$ & 0.3 \\
\hline
\end{tabular}




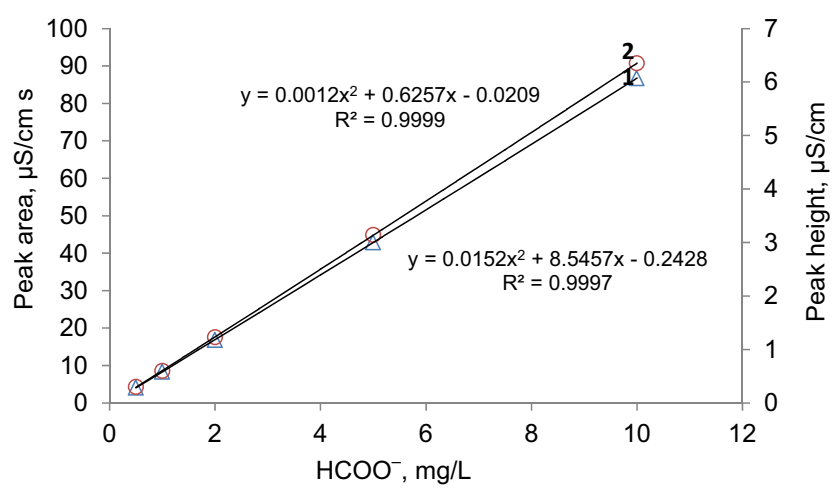

Fig. 3 Calibration curves for formate ions using 1 peak areas and 2 peak heights (Metrosep A Supp 7 column, $3.6 \mathrm{mmol} / \mathrm{L} \mathrm{Na}_{2} \mathrm{CO}_{3}$ eluent, $0.7 \mathrm{~mL} / \mathrm{min}$ )

60 min when using the IonPac AS9-HC column. The analysis time of the mixture of all ions on the IonPac AS9-HC column decreases in case of more concentrated eluent (ca. $30 \mathrm{~min}$ for $9 \mathrm{mmol} / \mathrm{L} \mathrm{Na}_{2} \mathrm{CO}_{3}$ ). The isolation of formate signal from the acetate is, however, worse under such conditions.

Five standard solutions containing the mixtures of formates with acetates and fluorides were used for the calibration procedure (Table 1). Each of the calibration solution was run triplicate. Two calibration curves were generated by plotting (1) the peak areas and (2) the peak heights against the concentrations of formate in the injected standards (Fig. 3). Both

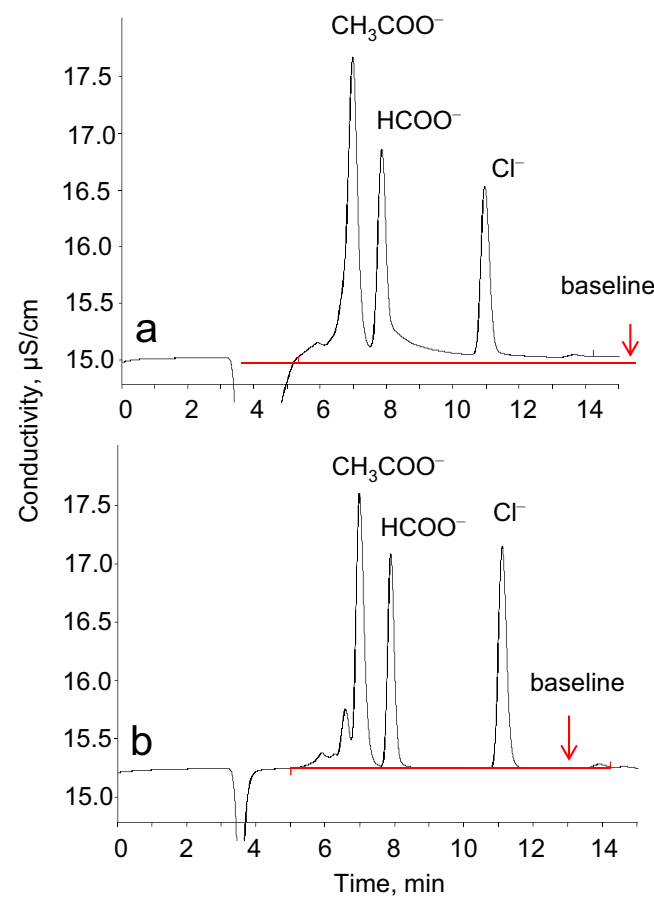

Fig. 4 The IC chromatograms of commercial Golden Rum. a Directly submitted to IC analysis. b After preliminary evaporation of ethanolic matrix (Metrosep A Supp 7 column, $3.6 \mathrm{mmol} / \mathrm{L} \mathrm{Na}_{2} \mathrm{CO}_{3}$ eluent, $0.7 \mathrm{~mL} / \mathrm{min})$

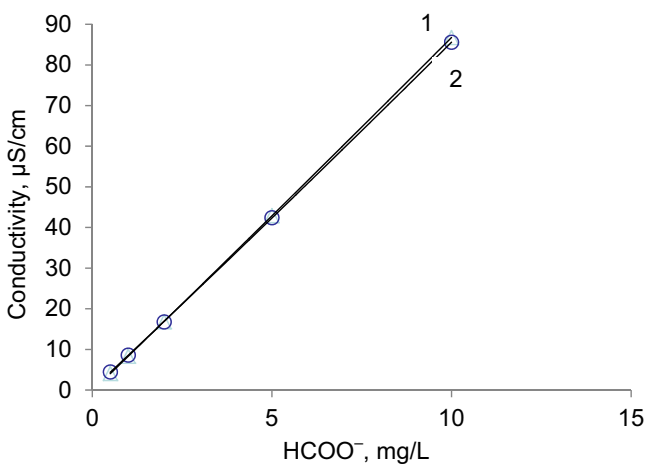

Fig. 5 Calibration curves for formate ions in 1 aqueous and 2 ethanolicaqueous (1:4) solutions

parameters, peak areas and peak heights, can make the basis of the quantitation procedure. Statistical data of formate results obtained using peak areas for quantitation are presented in Table 1. Detection limit (DL) for formate ions was evaluated in the analysis of synthetic mixtures containing their minimum concentrations being detected: $0.25 \mathrm{mg} / \mathrm{L}\left(\mathrm{HCOO}^{-}\right)$in the mixture with $0.25 \mathrm{mg} / \mathrm{L}\left(\mathrm{CH}_{3} \mathrm{COO}^{-}\right)$and $0.05 \mathrm{mg} / \mathrm{L}\left(\mathrm{F}^{-}\right)$ ions and calculated as a triple standard deviation (SD) of the results $(n=10)$. DL and quantitation limit (QL) were evaluated as 0.014 and $0.042 \mathrm{mg} / \mathrm{L}$, respectively. Calibration range corresponded to $0.04-10.0 \mathrm{mg} / \mathrm{L}$ of formate ions.

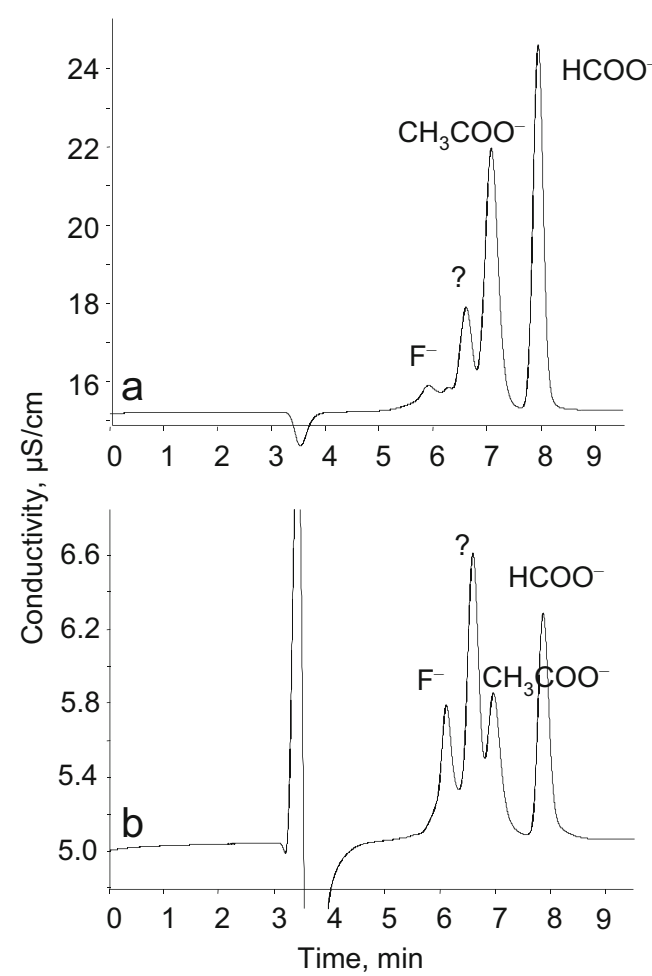

Fig. 6 The IC chromatograms of commercial. a Rum and b vodka samples (A Supp 7 column, $3.6 \mathrm{mmol} / \mathrm{L} \mathrm{Na}_{2} \mathrm{CO}_{3}$ eluent, $0.7 \mathrm{~mL} / \mathrm{min}$ ) (?- unidentified peak) 
Table 2 The results for formate in the examined commercial spirit drinks $(n=3)$

Golden Rum

Sample, $\mathrm{mL} \quad$ Examined solution, $\mathrm{mg} / \mathrm{L}$

$\begin{array}{cc}5 & 3.10 \\ 10 & 6.29 \\ 25 & 15.39\end{array}$

Statistical data (original products)

$\bar{x}=3.11 \mathrm{mg} / \mathrm{L}, \mathrm{SD}=0.04 \mathrm{mg} / \mathrm{L}, \mathrm{CV}=1.1 \%$
Absolwent vodka

Sample, $\mathrm{mL} \quad$ Examined solution, $\mathrm{mg} / \mathrm{L}$

Original product, $\mathrm{mg} / \mathrm{L}$

$\begin{array}{llll}3.10 & 10 & 0.42 & 0.21 \\ 3.15 & 25 & 1.05 & 0.21 \\ 3.08 & 50 & 2.19 & 0.22\end{array}$

$\bar{x}=0.21 \mathrm{mg} / \mathrm{L}, \mathrm{SD}=0.03 \mathrm{mg} / \mathrm{L}, \mathrm{CV}=1.8 \%$

\section{Analysis of Alcoholic Drink Samples}

Two typical Polish alcoholic products, vodka (Absolwent) and rum (Golden Rum), available on the local market were analyzed for the confirmation of the applicability of the described chromatographic procedure for the determination of formates in such kind of samples. The samples of 5-50 mL taken from the commercial bottles were preliminary evaporated to ca. $1 \mathrm{~mL}$ to minimize the amount of alcoholic matrix. The evaporation was carried out under IR lamp (located ca. $20 \mathrm{~cm}$ above the surface of the sample), and the residue was diluted with deionized water to $5.0 \mathrm{~mL}$ of the final volume prior to submitting to chromatographic analysis. The experiments have shown that such approach improves baseline separation of formate signal. Figure 4 shows the IC chromatograms of the commercial rum sample directly submitted to IC analysis and after preliminary evaporation of ethanolic matrix. Lower amount of alcoholic matrix provides better adjustment of formate signal to the baseline. Changing the matrix from pure water to ethanol-water (1:4) does not practically affect quantification results. The regression curves for formate ions in pure aqueous and ethanolic-aqueous matrices calculated on the basis of peak areas are presented in Fig. 5.

The ion chromatograms of the examined spirit products under the conditions used are presented in Fig. 6. The

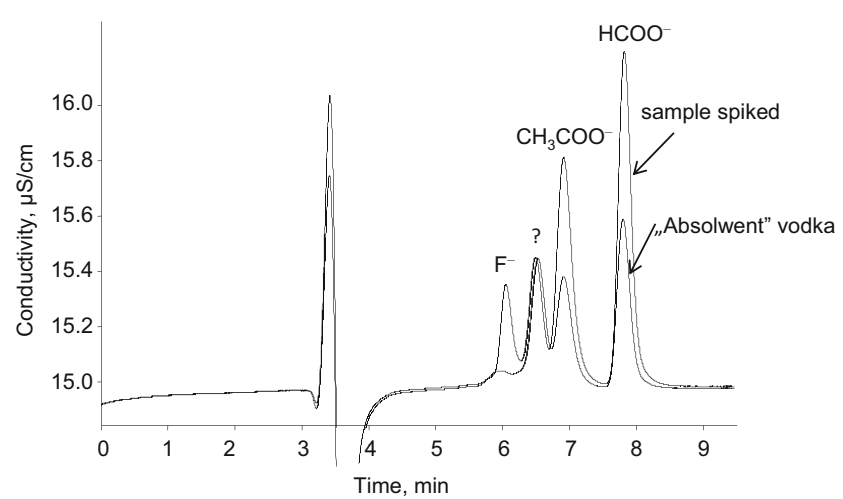

Fig. 7 The IC chromatograms of the original and spiked (formate $(0.2 \mathrm{mg} / \mathrm{L})$, fluoride $(0.04 \mathrm{mg} / \mathrm{L})$, and acetate $(0.60 \mathrm{mg} / \mathrm{L}))$ Absolwent vodka sample (? - unidentified peak) evaluated contents of formate in both examined spirit drinks are presented in Table 2. Higher amounts of formates were determined in rum $(3.11 \pm 0.04 \mathrm{mg} / \mathrm{L})$ as compared with vod$\mathrm{ka}(0.21 \pm 0.03 \mathrm{mg} / \mathrm{L})$ samples. Spike recovery of formates (standard solution added to the commercial sample prior to the evaporation) was in the range of 96.0-107.0\%. Figure 7 presents the chromatograms of the vodka sample spiked with formate $(0.2 \mathrm{mg} / \mathrm{L})$, fluoride $(0.04 \mathrm{mg} / \mathrm{L})$, and acetate $(0.60 \mathrm{mg} / \mathrm{L})$ ions.

The developed method offers the possibility of rapid evaluation of the multi-anionic profile of alcoholic drinks. Figure 8 presents the whole anionic chromatogram of the examined Golden Rum sample under optimum conditions evaluated in this work (Metrosep A Supp 7 column, $3.6 \mathrm{mmol} / \mathrm{L}$ $\mathrm{Na}_{2} \mathrm{CO}_{3}(0.7 \mathrm{~mL} / \mathrm{min})$ eluent). The anionic profile can serve as a criterion for distinguishing among spirit drinks, including their adulteration and authentication.

\section{Conclusions}

Ion chromatography provides the possibility of rapid evaluation of the multi-anionic (small organic acids and common inorganic anions) profile of alcoholic drinks. Two analytical

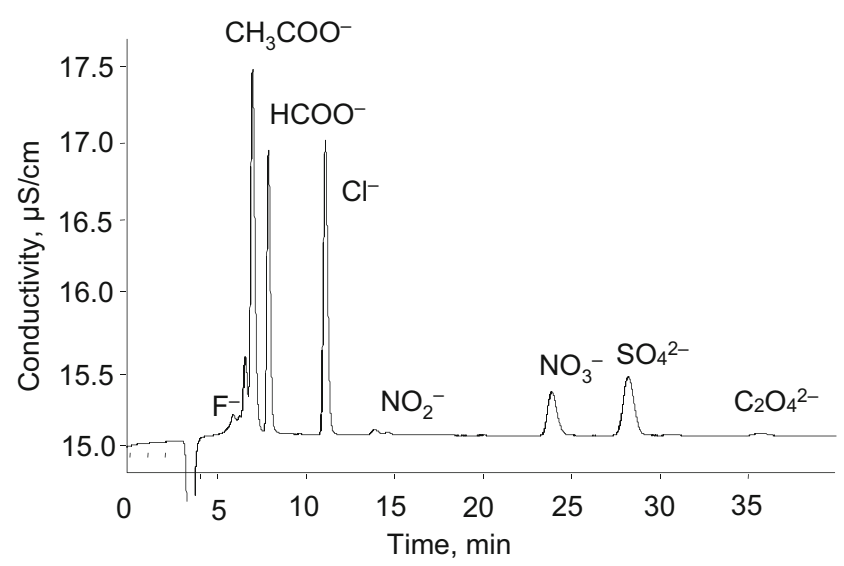

Fig. 8 The multi-anionic profile of Golden Rum sample (A Supp 7 column, $3.6 \mathrm{mmol} / \mathrm{L} \mathrm{Na}_{2} \mathrm{CO}_{3}$ eluent, $0.7 \mathrm{~mL} / \mathrm{min}$ ) 
columns examined, Metrosep A Supp 7 from Metrohm and IonPac AS9-HC from Dionex, allow effective isolation of formate signals from such kind of samples. The analysis time of the mixture of the examined organic $\left(\mathrm{HCOO}^{-}, \mathrm{CH}_{3} \mathrm{COO}^{-}\right.$, and $\left.\mathrm{C}_{2} \mathrm{O}_{4}{ }^{2-}\right)$ and common inorganic $\left(\mathrm{F}^{-}, \mathrm{Cl}^{-}, \mathrm{NO}_{2}{ }^{-}, \mathrm{Br}^{-}\right.$, $\mathrm{NO}_{3}{ }^{-}, \mathrm{HPO}_{4}{ }^{2-}$, and $\mathrm{SO}_{4}{ }^{2-}$ ) ions is shorter (ca. $35 \mathrm{~min}$ ) when using the Metrosep A Supp 7 column as compared with the IonPac AS9-HC column (ca. $60 \mathrm{~min})\left(3.6 \mathrm{~mol} / \mathrm{L} \mathrm{Na}_{2} \mathrm{CO}_{3}\right.$ eluent in both cases). The described analytical procedure is applicable to direct analysis of alcoholic commercial products for the content of formates. Minimizing of the amount of alcoholic matrix by preliminary careful evaporation of the sample under IR light source improves baseline separation of formate ion signal. The evaluated amounts of formate ions in the examined rum samples were about 15 times higher (ca. $3 \mathrm{mg} / \mathrm{L}$ ) than in vodka samples (ca. $0.2 \mathrm{mg} / \mathrm{L}$ ) examined.

Acknowledgements Financial support of the work by the Warsaw University of Technology is kindly acknowledged.

\section{Compliance with Ethical Standards}

Conflict of Interest Maria Balcerzak declares that she has no conflict of interest. Dawid Kapica declares that he has no conflict of interest.

Ethical Approval This article does not contain any studies with human participants or animals performed by any of the authors.

Informed Consent Not applicable.

Open Access This article is distributed under the terms of the Creative Commons Attribution 4.0 International License (http://creativecommons.org/ licenses/by/4.0/), which permits unrestricted use, distribution, and reproduction in any medium, provided you give appropriate credit to the original author(s) and the source, provide a link to the Creative Commons license, and indicate if changes were made.

\section{References}

Arbuzov VN, Savchuk SA (2002) Identification of vodkas by ion chromatography and gas chromatography. J Anal Chem 57:428-433

Brudin SS, Shellie RA, Haddad PR, Schoenmakers PJ (2010) Comprehensive two-dimensional liquid chromatography: ion chromatography $\times$ reversed-phase liquid chromatography for separation of low-molar-mass organic acids. J Chromatogr A 1217:6742-6746

Hovda KE, Urdal P, Jacobsen D (2005) Increased serum formate in the diagnosis of methanol poisoning. J Anal Toxicol 29:586-588

Janiszewska J, Balcerzak M (2013) Analytical problems with the evaluation of human exposure to fluorides from tea products. Food Anal Methods 6:1090-1098

Käkölä JM, Alén RJ, Isoaho JP, Matilainen RB (2008) Determination of low-molecular-mass aliphatic carboxylic acids and inorganic anions from kraft black liquors by ion chromatography. J Chromatogr A 1190:150-156

Kapur BM, Vandenbroucke AC, Adamchik Y, Lehotay DC, Carlen PL (2007) Formic acid, a novel metabolite of chronic ethanol abuse, causes neurotoxicity, which is prevented by folic acid. Alcohol Clin Exp Res 31:2114-2120

Kinoshita H, Ijiri I, Ameno S, Tanaka N, Kubota T, Tsujinaka M, Watanabe R, Ameno K (1998) Combined toxicity of methanol and formic acid: two cases of methanol poisoning. Int J Legal Med 111: 334-335

Klampfl CW, Buchberger W, Haddad PR (2000) Determination of organic acids in food samples by capillary zone electrophoresis. J Chromatogr A 881:357-364

Kontozova-Deutsch V, Krata A, Deutsch F, Bencs L, Van Grieken R (2008) Efficient separation of acetate and formate by ion chromatography: application to air samples in a cultural heritage environment. Talanta 75:418-423

Kontozova-Deutsch V, Deutsch F, Bencs L, Krata A, Van Grieken R, De Wael K (2011) Optimization of the ion chromatographic quantification of airborne fluoride, acetate and formate in the Metropolitan Museum of Art, New York. Talanta 86:372-376

Kruse JA (1992) Methanol poisoning. Intensive Care Med 18:391-397

Kubáň P, Boček R (2013) Direct analysis of formate in human plasma, serum and whole blood by in-line coupling of microdialysis to capillary electrophoresis for rapid diagnosis of methanol poisoning. Anal Chim Acta 768:82-89

Kubán̆ P, Foret F, Boček R (2013) Capillary electrophoresis with contactless conductometric detection for rapid screening of formate in blood serum after methanol intoxication. J Chromatogr A 1281:142-147

Kubáň P, Durč P, Bittová M, Foret F (2014) Separation of oxalate, formate and glycolate in human body fluid samples by capillary electrophoresis with contactless conductometric detection. J Chromatogr A 1325:241-246

Kuo CY (1998) Improved application of ion chromatographic determination of carboxylic acids in ozonated drinking water. J Chromatogr A 804:265-272

Lachenmeier DW, Attig R, Willi F, Athanasakis C (2003) The use of ion chromatography to detect adulteration of vodka and rum. Eur Food Res Technol 218:105-110

Lee XQ, Huang DK, Lou DW, Pawliszyn J (2012) Needle trap extraction for GC analysis of formic and acetic acids in aqueous solution. J Sep Sci 35:1675-1681

Lee XQ, Zhang LK, Huang DK, An N, Yang F, Jiang W, Fang B (2013) Analysis of the stable carbon isotope composition of formic and acetic acids. Anal Biochem 436:178-186

Ligor M, Jarmalaviciene R, Szumski M, Maruška A, Buszewski B (2008) Determination of volatile and non-volatile products of milk fermentation processes using capillary zone electrophoresis and solid phase microextraction coupled to gas chromatography. J Sep Sci 31:27072713

Lodi S, Rossin G (1995) Determination of some organic acids in sugar factory products. J Chromatogr 706:375-383

Magne V, Mathlouthi M, Robilland B (1998) Determination of some organic acids and inorganic anions in beet sugar by ionic HPLC. Food Chem 61:449-453

Pantučkova P, Kubáň P, Boček P (2013) Supported liquid membrane extraction coupled in-line to commercial capillary electrophoresis for rapid determination of formate in undiluted blood samples. J Chromatogr A 1299:33-39

Rantakokko P, Mustonen S, Yritys M, Vartiainen T (2004) Ion chromatographic method for the determination of selected inorganic anions and organic acids from raw and drinking waters using suppressor current switching to reduce the background noise. J Liquid Chromatogr \& Related Technol 27:829-842

Ryhl-Svendsen M, Glastrup J (2002) Acetic acid and formic acid concentrations in the museum environment measured by SPME-GC/ MS. Atm Environ 36:3909-3916

Sokoro AR, Lehotay D, Eichhorst J, Treble R (2007) Quantitative endogenous formate analysis in plasma using headspace gas chromatography without a headspace analyzer. J Anal Toxicol 31:342-346 
Suárez-Luque S, Mato I, Huidobro JF, Simal-Lozano J, Sancho MT (2006) Capillary zone electrophoresis method for the determination of inorganic anions and formic acid in honey. J Agric Food Chem 54:9292-9296

Tanaka E, Honda K, Horiguchi H, Misawa S (1991) Postmortem determination of the biological distribution of formic acid in methanol intoxication. J Forensic Sci 36:936-938

Travassos Lemos MA, Cassella RJ, de Jesus DP (2015) A simple analytical method for determining inorganic anions and formate in virgin olive oils by capillary electrophoresis with capacitively coupled contactless conductivity detection. Food Control 57:327-332
Viinamäki J, Rasanen I, Vuori E, Ojanperä I (2011) Elevated formic acid concentrations in putrefied post-mortem blood and urine samples. Forensic Sci Int 208:42-46

Weiss J (2004) Handbook of ion chromatography. Weinheim, Wiley$\mathrm{VCH}$

Walford SN (2002) Applications of ion chromatography in cane sugar research and process problems. J Chromatogr A 956:187-199

Wallage HR, Watterson JH (2008) Formic acid and methanol concentrations in death investigations. J Anal Toxicol 32:241-247

Wojtczak M, Antczak A, Lisik K (2013) Contamination of commercial cane sugars by some organic acids and some inorganic anions. Food Chem 136:193-198 